\title{
Estrogenic in vitro assay on mouse embryonic Leydig cells
}

\author{
GINA LA SALA, DONATELLA FARINI and MASSIMO DE FELICI* \\ Department of Public Health and Cell Biology, Section of Histology and Embryology, \\ University of Rome "Tor Vergata", Rome, Italy
}

\begin{abstract}
We and others have reported that mouse embryonic testes contain a subpopulation of somatic cells expressing estrogen receptor $\alpha$ (ER $\alpha)$. In order to provide evidence for a possible direct estrogen effect on mammalian testes from the early stage of their differentiation, here we devised a method for the in vitro culture of the ER $\alpha$-expressing cells from 12.5 days post coitum mouse testes and their transfection with plasmids containing the classical estrogen responsive element (ERE) or the alternative estrogen AP-1 responsive element upstream of the luciferase reporter gene (ERE-Luc and AP-1-Luc). StAR immunopositivity of the most part of the ER $\alpha+$ cells grown in culture and subjected to the estrogenic assay, allowed their identification as embryonic Leydig cells. Maximum induction of the ERE-Luc activity was achieved with $10 \mathrm{nM}$ 17- $\beta$ estradiol (E2), from 1.7 to 3-fold in such cells and from 2.3 to 5.7-fold in MCF-7 cells used for comparison; the anti-estrogen ICI 182.780 abolished such effects. AP-1-Luc was less sensitive to E2 in both cell types (10 nM E2, 1.2 to 2.7-fold increase in embryonic Leydig cells; about 3-fold in MCF-7 cells) and the effect was not ICl-dependent. Eventually, we stimulated the transfected cells with various xenoestrogens such as lindane, bisphenol A or mono-(2-ethylhexyl) pthalate and with the phytoestrogen zeralenone obtaining evidence for ERE-Luc, but not AP-1-Luc stimulation in embryonic Leydig cells. These results represent evidence of functional ER $\alpha$-dependent genomic pathways in embryonic Leydig cells and describe an in vitro assay suitable for evaluating the activity of putative estrogenic compounds on such cells.
\end{abstract}

KEY WORDS: 17- $\beta$-estradiol, lindane, ZEA, MEHP, BPA, Leydig cells, ERE, AP-1

\section{Introduction}

Estrogens are key regulators of growth, differentiation and function in a broad range of target tissues, including the male and female reproductive tracts, mammary gland, bone, brain and the cardiovascular system. The biological effects of estrogens are mediated through estrogen receptor a $(E R \alpha)$ and estrogen receptor $\beta(E R \beta)$, which belong to a large superfamily of nuclear receptors that act as ligand-activated transcription factors (for a review Mangelsdorf et al., 1995). The classical mechanism of activation of ERs depends on ligand binding to the receptors, after which the receptors dimerize and bind to estrogen response elements (EREs) located in the promoters of estrogen-responsive genes (McKenna etal., 1999; Klein-Hitpass etal., 1989). ERs may also regulate gene expression in the absence of DNAbinding by modulating the activities of other transcription factors via protein-protein interactions on DNA. This mechanism is referred to as cross-talk and is common for several nuclear receptors. For example, ligand-bound ERs upregulate and downregulate transcription from genes that contain activator protein (AP)-1 sites, binding sites for the c-Jun/c-Fos complex, in a manner that depends on the type of cells and the subtype of ERs.

In 1993, Sharpe and Skakkebaek formulated the hypothesis that the increased concentration in environment and in food of human made compounds that mimic the action of estrogens termed xenoestrogens, was responsible for increased disorder of the male reproductive function termed Testicular Dysgenesis Syndrome (TDS), including decrease of sperm count, increase in the incidence of testicular cancer and hypospadias and cryptorchidism (Sharpe and Skakkebaek, 1993). They then argued that the exposure to xenoestrogens during fetal and neonatal

\footnotetext{
Abbreviations used in this paper: AP-1, activator protein-1; BPA, bisphenol A; DES, diethylstilbestrol; E2, 17- $\beta$-estradiol; EGFP, enhanced green fluorecence protein; ER $\alpha$, estrogen receptor $\alpha$; ERE, estrogen dependent element; Luc, luciferase; MEHP, mono-(2-ethylhexyl) pthalate; MIS, mullerian inhibitory substance; SF-1, steroidogenic factor-1; StAR, steroidogenic acute regulatory; TDS, testicular dysgenesis syndrome; ZEA, zeralenone.
}

\footnotetext{
*Address correspondence to: Massimo De Felici. Dipartimento di Sanità Pubblica e Biologia Cellulare, Università di Roma "Tor Vergata", Via Montpellier, 1, I-00173 Roma, Italy. Fax: +39-06-7259-6172. e-mail: defelici@uniroma2.it
} 
period was the origin of this syndrome (Skakkebaek et al., 2001). A prerequisite of such hypothesis is that reproductive tissues and gonads express functional ERs from early stages of development. Several studies actually reported that ERs are expressed in reproductive tissues and gonads from early stages of embryo development in mammals, including humans (Saunders et al., 1998, Jefferson et al., 2000, Vicini et al., 2006). In particular, we and others have reported that mouse embryonic testes from 12.5 dpc onward contain a subpopulation of somatic cells, identifiable mostly as Leydig cells, expressing $\mathrm{ER} \alpha$ (Greco et al., 1992; Nielsen et al., 2000; Moe-Beherens et al., 2003). This marks testes as a possible target for estrogens and estrogenic compounds from early stages of development.

Results are actually accumulating about ER $\alpha$-dependent estrogen and estrogenic effects on endocrine functions of fetal Leydig cell (Delbes et al., 2005; Cederroth et al., 2007). No simple assays exist, however, to evidence estrogenic activity at genomic level of compounds on ER $\alpha$ expressing cells within the embryonic testes. Aim of this work was to verify the presence of functional $E R \alpha$ in such cells, defined by us embryonic Leydig cells, using an ERE-and AP-1-Luc assay that could be used to quantify the genomic activity of estrogens and estrogenic compounds on such cells.

\section{Results and Discussion}

RT-PCR analyses carried out to verify the expression of ER transcripts on testis SCs after 3 days of culture and MCF-7 cells used as control, confirmed the expression of $E R \alpha$ and not of ER $\beta$ in either cell types (Fig. 1).

Using IF with antibodies specific for the three main somatic cell types of the testis, namely anti-MIS for Sertoli cells, anti-Desmin for myoid cells and anti-StAR for Leydig cells, we next estimated that under our culture conditions the percentages of cells positive for these markers after three days of culture were (mean \pm standard error) $12 \pm 2.7 \%$ for MIS, $20 \pm 1.8 \%$ for Desmin and 50 $\pm 6.5 \%$ for StAR (Fig. 2). On the basis of such expression, we consider these cells as Sertoli, myoid cell precursors and embryonic Leydig cells, respectively. Moreover, while virtually all StAR+ cells were $E R \alpha+$ (Fig. 2D), only about $10 \%$ of the $E R \alpha+$ cells were StAR-. Overall these observations indicated that around $60 \%$ of the cells to be subjected to the ERE- and AP-1-Luc assay expressed $E R \alpha$ and that the large majority of such cells being StAR+ could be identified as embryonic Leydig cells. Since in preliminary experiments, using pEGFP-C1 construct, the efficiency of transfection of the embryonic Leydig StAR+ER $\alpha+$ cells was around $30 \%$ and the number of other types of transfected cells was less that $5 \%$ (not shown), we attribute to the embryonic Leydig cells the results of the estrogenic assays reported below. In order to verify the functionality of $E R \alpha$ in such cells, we next transfected cultured testis SCs with ERE- and AP-1-Luc plasmids and then after $24 \mathrm{hr}$ of starvation in serum-free medium, stimulated them with 1-100 nM E2 for further $24 \mathrm{~h}$. The results of the ERE-Luc assay show maximal response of $2.8 \pm 0.4$-fold stimulation at $10 \mathrm{nM}$ E2 relative to vehicle-treated controls (Fig. 3A). Similar results were obtained when the assay were carried out on MCF-7 cells (Fig. 3B). In accord to previous results (Balaguer et al., 2001), however, in these cells the maximal effect achieved with $10 \mathrm{nM}$ E2 reached a significant higher value of $5.7 \pm 0.7$-fold stimulation. In both cell types, $10 \mathrm{nM}$ E2 stimulation was abolished by the presence of $10 \mu \mathrm{M} I C I$. The AP-1-Luc assay carried out on fractions enriched in embryonic Leydig cells and MCF-7 cells showed that in both cell types AP-1 site was less responsive to the hormone. In fact, we observed only $1.76 \pm 0.23$-fold and $3 \pm 0.15$ fold stimulation by $10 \mathrm{nM}$ E2 in fractions enriched in embryonic Leydig cells and MCF-7 cells, respectively. Interestingly, ICI failed to inhibit this effect (Fig. 4). The low activity of the AP-1-Luc construct reported here is in line with the notion that $E R \alpha$ is a weaker activator of AP-1 in comparison to ER $\beta$, while the lack of the $\mathrm{ICl}$ inhibitory effect can be explained by the fact that ERs can enhance AP-1 activity through two different mechanisms (for a review, see Kushner et al., 2000). It is actually well established that ER action at EREs is mediated by transactivation functions. $E R \alpha$ contains two separate transactivation functions, AF-1 and AF-2, which synergize strongly to give the overall level of estrogen response. AF-2 consists of a small hydrophobic patch on the surface of the estrogen-liganded ligand binding domain (LBD). ERs can enhance AP-1 activity in a manner that requires ER transactivation functions, but not the ER-DNA binding domain (DBD) or with a mechanism that is independent of ER activation functions, but does require the ER-DBD. While the former is activated by estrogens, the latter is activated by antiestrogens, especially those with high antiestrogenic potential like ICI (for a review, see Kushner et al., 2000).
A

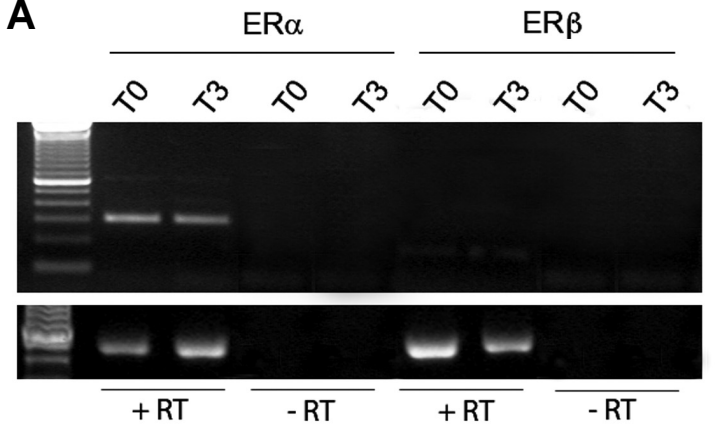

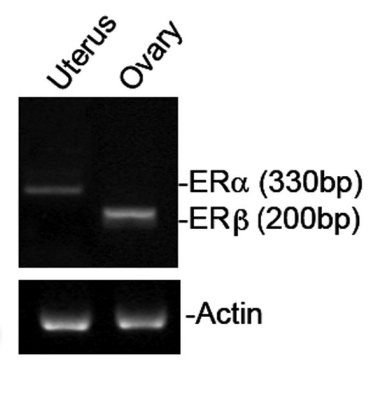

B

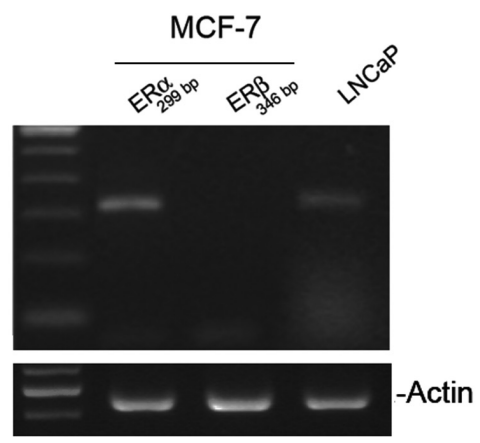

Fig. 1. Expression of ER $\boldsymbol{\alpha}$ and ER $\boldsymbol{\beta}$ transcripts in cultured testis somatic cells (SCs) and MCF-7 cells. RT-PCR analyses on SCs obtained from $12.5 \mathrm{dpc}$ testes and cultured for 0 and 3 days (A) and on MCF-7 cells (B). Both cell types show the presence of ER $\alpha$ but not of ER $\beta$. Uterus and ovary were used as positive control for $m E R \alpha$ and $m E R \beta$, respectively; LNCaP cells was used as control for $h E R \beta$. RT, retrotrascriptase. 

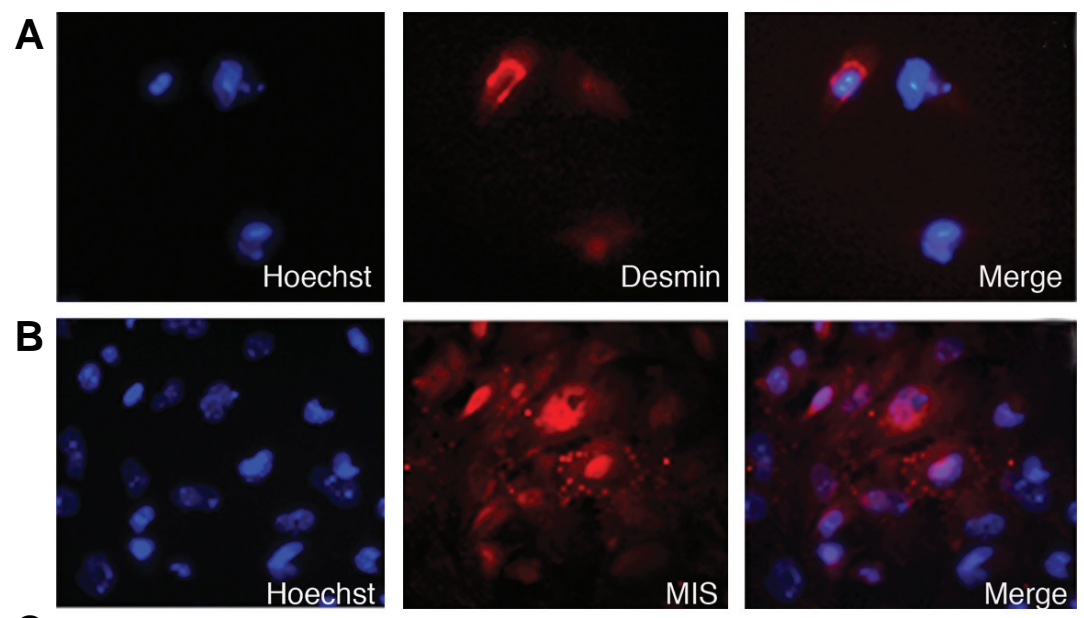

C
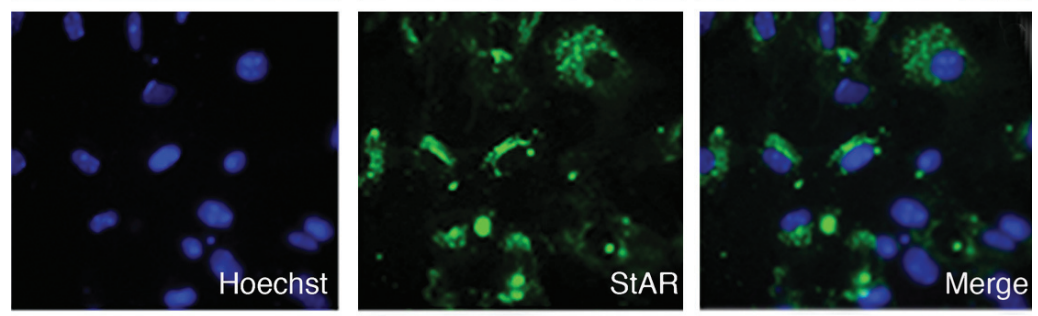

D
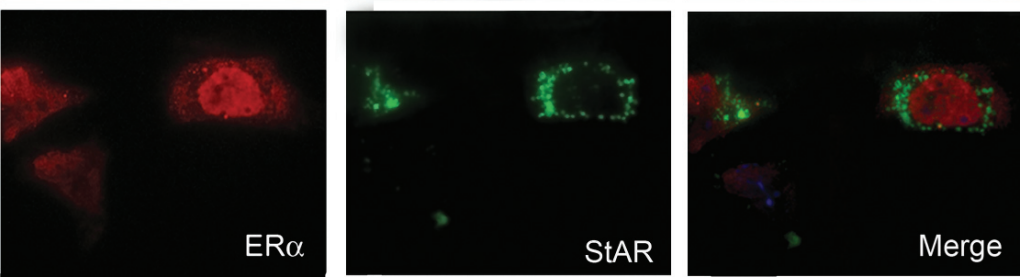

Fig. 2. Immunofluorescence on testis somatic cells (SCs) after 3 days of culture. Representative fields of SCs stained as follows: Desmin (A) for myoid cells, MIS (B) for Sertoli cells and StAR (C) for Leydig cells; (D) double immunolocalization of $E R \alpha+$ and StAR+. Original magnification 40x.

Finally, to further validate our assay, we stimulated cultured fractions enriched in embryonic Leydig cells and MCF-7 cells with lindane, the $\gamma$ isomer of hexacyclohexane $(\gamma-\mathrm{HCH})$, bisphenol $\mathrm{A}$ (BPA, 2,2-bis (4hydroxyphen) propane), mono-(2-ethylhexyl) pthalate (MEHP) and zeralenone (ZEA), considered compounds with estrogenic activity (Traina et al., 2003; Washington etal., 2001; Okubo et al., 2003; Shier et al., 2001, and references herein). The results reported in Fig. 5, show that at concentrations able to elicit estrogen-dependent effect in MCF-7 cells in our assay and in literature (Balaguer et al., 2001, Martin et al., 1978, Ricupito et al., 2009, Steinmetz et al., 1996), these compounds stimulated ERE-Luc activity in fractions enriched in embryonic Leydig cells in a $\mathrm{ICl}-$ dependent manner at similar ( $3.1 \pm 0.5$ fold lindane and $3.33 \pm 0.2$-fold $B P A$ ) or higher $(4.6 \pm 0.1$ fold ZEA) level than E2 $(2.8 \pm 0.4$ fold). On the other hand, although $10 \mu \mathrm{M}$ MEHP appeared no estrogenic on MCF-7 (Fig. 5A) (see also Okubo et al., 2003), it caused $4.0 \pm 0.5$-fold increase of ERE-Luc activity in fractions enriched in embryonic Leydig cells in our assay. Not consistent inhibitory effect of $\mathrm{ICl}$ on the MEHP effect (Fig. 5A) suggests complex not canonical ER $\alpha$-dependent action of this compound on such cells. Interestingly, in the mouse in utero phthalate exposure altered development of fetal seminiferous cord and caused gonocyte multinucleation without modifying testosterone level (Gaido et al., 2007). Finally, all these compounds failed to significantly stimulate AP-1-Luc activity in fractions enriched in embryonic Leydig cells. With the exception of ZEA, they were, however, able to stimulate such activity in $\mathrm{ICl}$-independent manner in MCF-7 at levels comparable to those elicited by E2 (Fig. 4 and Fig. 5B). On the whole the comparison of estrogen responsiveness both in terms of ERE and AP-1-Luc activity allows to evidence significant less sensitivity in embryonic Leydig cells, than in MCF-7. This can be due to either higher levels of $E R \alpha$ or more efficient $E R \alpha$ signalling or both in these latter (Steinmetz et al., 1996; Balaguer et al., 2001).

Besides the above reported study on pthalates carried out by Gaido et al. (2007), several studies have demonstrated various effects of the prenatal exposure to estrogens and estrogenic compounds including environmental xenoestrogens, on the development of the rodent fetal testis (for a review, see Delbès et al., 2006 ; 2007). For example in the rat, in utero exposure from 11.5 to $15.5 d p c$ to $\mathrm{E} 2$ and various xenoestrogens altered expression of steroidogenic factor-1 (SF-1) in the fetal testis (Majdic et al., 1997) while BPA exposure on day 6-21 of gestation led to increased number of Sertoli cell. In culture, E2 and diethylstilbestrol (DES) caused various alteration in rat Leydig cells, Sertoli cells and gonocytes (Lassurguère et al., 2003). In the mouse, DES inhibited the expression of StAR protein in fetal testis (Guyot et al., 2004). Moreover using ER $\alpha$ knockout mice, it has been reported that endogenous estrogens inhibit fetal Leydig cell development (Delbès etal., 2005) and that $E R \alpha$ is a major contributor to estrogen-mediated testis dysgenesis and cryptorchidism (Cederroth et al., 2007). In spite of these

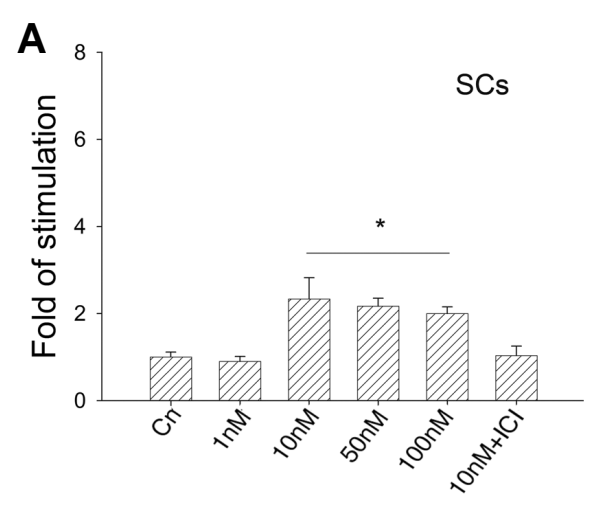

Fig. 3. ERE-Luc activity in testis SCs and MCF-7 cells stimulated by increasing concentrations of 17- $\beta$-estradiol (E2). (A) SCs (fraction enriched in embryonic Leydig cells), (B) MCF-7 cells. Data represent the mean \pm SE of at least three separate experiments. ${ }^{*}, p<0.05$ vs Control (Cn).

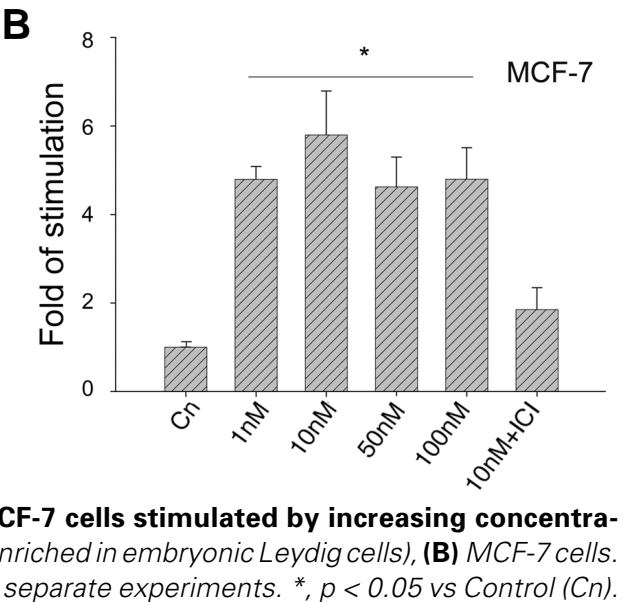




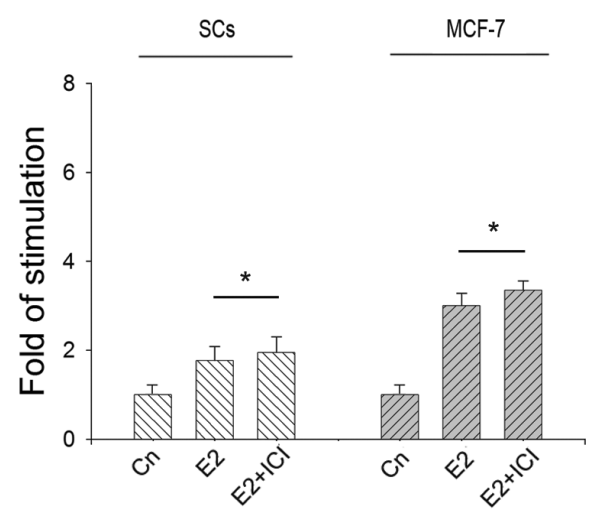

Fig. 4. AP-1-Luc activity in testis somatic cells (SCs; fraction enriched in embryonic Leydig cells) and MCF-7 cells stimulated by 10 nM 17$\boldsymbol{\beta}$-estradiol (E2). Data represent the mean \pm SE of at least three separate experiments. ${ }^{*}, p<0.05$ vs Control (Cn).

results, while the estrogen responsiveness of MCF-7 cell in term of proliferation and apoptosis or gene expression is well documented (Detre et al., 1999; Truchet et al., 2000; Inoue et al., 2002), little is known about the estrogen and xenoestrogen $E R \alpha-$ dependent effects on the embryonic Leydig cells. In this regard the results presented here are particular relevant since they constitute a clear evidence about the existence of functional ER $\alpha$ mediated genomic pathways in embryonic Leydig cells. Moreover, the methods described here represent simple in vitro assays suitable for a rapid screening of estrogenic action of compounds on mammalian embryonic testes. These can be used as basis for studies aimed to identify effects of estrogens and xenoestrogens on biological functions and gene expression in Leydig cells at the very early stage of their differentiation within the mammalian testes.

\section{Materials and Methods}

\section{Isolation and culture of somatic cells from $12.5 \mathrm{dpc}$ mouse testes and} MCF-7 cell culture

All experiments were carried out in compliance with the ethical provisions enforced by the European Union and authorized by the National Committee of the Italian Ministry of Health. CD-1 female mice (Charles River, Italy) were mated with CD-1 male mice and the detection of a vaginal plug the morning following mating was designated 0.5 day post coitum $(d p c)$. Somatic cells (SCs) were obtained from the $12.5 \mathrm{dpc}$ testes of CD1 mice embryos following the method described in Pesce etal., 1995. About $5 \times 10^{4}$ testis SCs in $500 \mu$ l of culture medium were seeded in each well of a 24-well Falcon dish. The culture medium consisted of phenol red-free DMEM with high glucose (GibcoBRL/Invitrogen, Italy) containing non essential amino acids, $0.1 \mathrm{mM}$ 2-mercaptoethanol, $2 \mathrm{mM} \mathrm{L}$-glutamine, 0.25 $\mathrm{mM}$ pyruvate, $75 \mathrm{mg} / \mathrm{L}$ penicillin-G, $50 \mathrm{mg} / \mathrm{L}$ streptomycin, $0.5 \mathrm{mg} / \mathrm{ml} \mathrm{N}$ acetyl-L-cysteine (NAC) and 5\% Horse Serum (HS) and $2.5 \%$ Fetal Calf Serum (FCS) (GibcoBRL/Invitrogen (Italy). Culture was carried out in a humidified incubator at $37^{\circ} \mathrm{C}$ in $5 \% \mathrm{CO}_{2}$ air. The MCF-7 human breast cancer cell line was purchased from ATCC (American Type Culture Collection, USA) and cultured in DMEM w/o phenol red, $5 \%$ fetal bovine serum (FBS), L-glutamine and antibiotics (GibcoBRL/Invitrogen, Italy).

\section{Immunofluorescence (IF)}

At the indicated time, cells were fixed in $4 \%$ paraformaldehyde, extensively washed and then permeabilized with Triton $0.2 \%$ for 5 min before incubation with the primary antibodies. Immunopositivity for Steroidogenic
Acute Regulatory (StAR), Mullerian Inhibitory Substance (MIS) and Desmin proteins was used as Leydig, Sertoli and myoid cell markers, respectively. Cells were incubated over night at $4{ }^{\circ} \mathrm{C}$ with anti-StAR (1:250) (Santa Cruz, USA, cat. No. sc25806), anti-MIS (1:50) (Santa Cruz, USA, cat. No. sc6886), and with anti-Desmin (1:20) (Amersham, Italy). All antibodies were diluted in PBS with 1\% BSA. Cells were washed and transferred in secondary antibodies, anti-rabbit (StAR), anti-goat (MIS) and anti-mouse (Desmin) lgGs were added (1:500) for $1 \mathrm{~h}$. Negative controls, omitting the primary antibodies, were included. IF for ER $\alpha$ detection was performed using anti-ER $\alpha$ antibody H222 (a kind gift by Prof. GL Green, University of California, USA) following the protocol for permeabilized cells described in Norfleet etal. (1999). For double staining, after fixation and permeabilization according to the ER $\alpha$ detection protocol and StAR immunolocalization as reported above, SCs were incubated with the anti-ER $\alpha$ for $2 \mathrm{~h}$ and then with anti-rat lgGs made in rabbit for $30 \mathrm{~min}$ at room temperature.

\section{$R T-P C R$ for $E R \alpha$ and $E R \beta$}

Total RNA was extracted from cultured testis SCs and from MCF-7 cells with RNeasy minikit (Qiagen, Italy) in accordance to the manufacturer's instructions. First-strand cDNA synthesis was performed as follows: $200 \mathrm{ng}$ total RNA was reverse transcribed by $50 \mathrm{U}$ of Superscript ${ }^{\mathrm{TM}}$ II (Invitrogen, Italy) using $50 \mathrm{ng}$ random hexamers, in the presence of $0.5 \mu \mathrm{M}$ deoxynucleotide triphosphates in a final volume of $20 \mu \mathrm{l}$. DNA contamina-

A

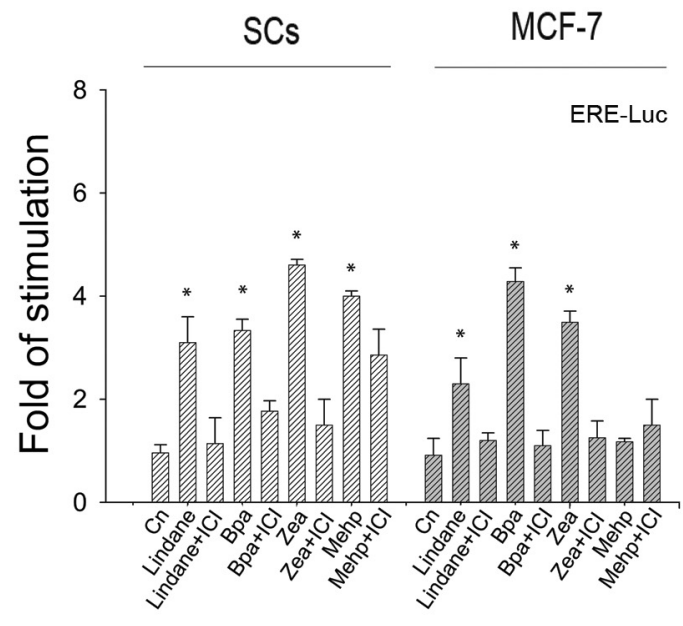

B

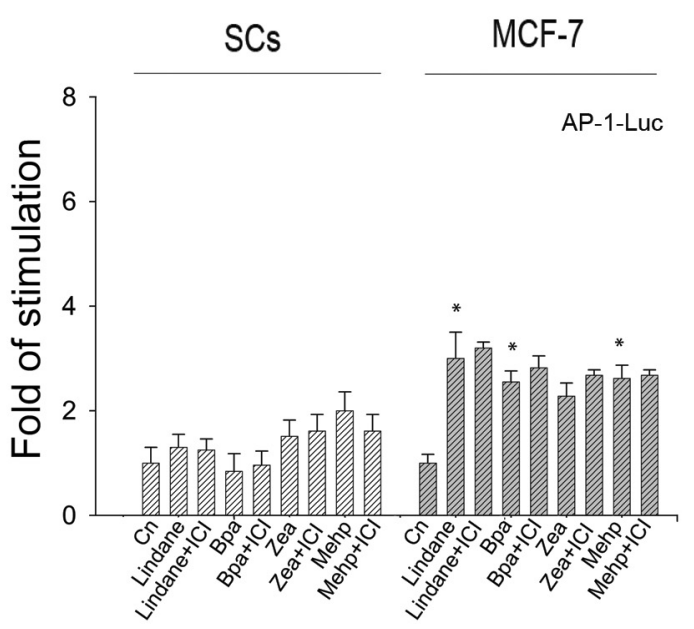

Fig. 5. ERE-Luc and AP-1-Luc activity in testis somatic cells (SCs; fraction enriched in embryonic Leydig cells) and MCF-7 cells stimulated by $10 \mu \mathrm{M}$ lindane, $25 \mu \mathrm{M}$ BPA, $10 \mu \mathrm{M}$ ZEA or $10 \mu \mathrm{M}$ MEHP. (A) ERE-Luc, (B) AP-1-LuC. ${ }^{*}, p<0.05$ vs Control (Cn). 
tion or PCR carry over controls were performed omitting reverse transcriptase during reverse transcription. The reaction mixture was incubated for $1 \mathrm{~h}$ at $42^{\circ} \mathrm{C}$, then heat denatured for $15 \mathrm{~min}$ at $75^{\circ} \mathrm{C} 3 \mu$ of the obtained cDNA was used to amplify $E R \alpha, E R \beta$. Primer sequences were:

mER $\alpha$ : 5'-ACCATTGACAAGAACCGGAG-3'

5'-ATAGATCATGGGCGGTTCAG-3'

mER $\beta$ : 5'-TCTGCATAGAGAAGCGATGA-3

5'-GGCATTCTACAGTCCTGCTG-3'

$\mathrm{hER} \alpha$ 5'-AGACATGAGAGCTGCCAACC-3

5'-GCCAGGCACATTCTAGAAGG-3

hERB 5'-TCACATCTGTATGCGGAACC-3'

5'-CGTACCACTTCCGAAGTCGG-3'

Reactions were performed using the following reagents: $0.5 \mu \mathrm{M}$ of primers, Taq polymerase $(2 \mathrm{U} / \mathrm{tube})$ in a final volume of $20 \mu \mathrm{l}$. The amplification consisted of: 35 cycles at $95^{\circ} \mathrm{C}$ for $1 \mathrm{~min}, 58^{\circ} \mathrm{C}$ for $1 \mathrm{~min}, 72^{\circ} \mathrm{C}$ for $1 \mathrm{~min}$ for $\mathrm{mER} \alpha ; 35$ cycles $95^{\circ} \mathrm{C}$ for $1 \mathrm{~min}, 62^{\circ} \mathrm{C}$ for $1 \mathrm{~min}, 72^{\circ} \mathrm{C}$ for $2 \mathrm{~min}$ for mER $\beta$; 35 cycles $95^{\circ} \mathrm{C}$ for $1 \mathrm{~min}, 58^{\circ} \mathrm{C}$ for $30 \mathrm{sec}, 72^{\circ} \mathrm{C}$ for $30 \mathrm{sec}$ for hER $\alpha / \mathrm{hER} \beta$. Adult uterus and ovary served as positive controls for $\mathrm{mER} \alpha$ and $\mathrm{mER} \beta$ respectively, while human prostate carcinoma cell line (LNCaP) as a positive control for hER $\beta$.

\section{ERE-and AP-1-Luc assay}

After $24 \mathrm{~h}$ of culture, testis SCs in each well of a 24-well Falcon dish were transfected with $1 \mu \mathrm{g}$ of $\mathrm{pEGFP}-\mathrm{C} 1$ construct (Clonetech) or an ERE- or AP1 dependent luciferase reporter gene (3XERE-TATA-Luc, provided by Prof. DP McDonnell, Duke University, North Caroline, USA; AP-1-Luc, Stratagene) and Renilla luciferase reporter gene (10 $\mathrm{ng}$ ) as an internal transfection control using the TransFastTM Transfection Reagent (Promega, Italy) according to the manufacturer's instructions. After $24 \mathrm{~h}$ of culture, transfected cells were extensively washed and starved for $24 \mathrm{~h}$ in the same culture medium as above but without serum. Eventually, cells were incubated in the presence of $17-\beta$-estradiol (E2) lindane $(\gamma-\mathrm{HCH})$, bisphenol $A$ (BPA), zeralenone (ZEA) (Sigma, Italy) or mono-(2-ethylhexyl) pthalate (MEHP) (TCI, Japan) at the indicated concentrations with or without $10 \mu \mathrm{M}$ of the antiestrogen ICI 182.780 (ICI) (Tocris, UK) for additional $24 \mathrm{~h}$. Stock solutions of compounds were prepared in ethanol and freshly diluted at the final concentrations with the culture medium. Control cultures were treated with vehicle alone (1:1000 v/v ethanol). At the end of the incubation, cells in each well were harvested and lysed in $250 \mu$ l passive lysis buffer (PLB) (Dual-Luciferase Reporter Assay System, Promega, Italy) for 15 min at room temperature. Cell lysates were cleared for $30 \mathrm{sec}$ by centrifugation at top speed in a refrigerated microcentrifuge and transferred to a fresh tube prior to reporter enzyme analysis. Ten microliters of cell lysates from each well were mixed with $100 \mu$ l of Luciferase Assay Reagent II (LAR II) (Promega, Italy), and the ERE-firefly luciferase activity was determined using a biocounter luminometer. For the assessment of the Renilla luciferase activity, $100 \mu \mathrm{l}$ of Stop \& GloR Reagent were added to the same sample.

\section{Statistics}

All experiments were replicated at least three times. The means were tested for homogeneity of variance and analyzed by ANOVA. The level of significance was set at $\mathrm{P}=0.05 \%$ and $\mathrm{P}=0.01 \%$.

\section{Acknowledgements}

The present study was supported by European Community project "GENDISRUPT" (QLK4CT-2002-02403) and Ministero del Lavoro e della Previdenza Sociale grant n. 1650. We are in debt with Prof. GL Green for the anti ERo antibody and with DP MCDonnell for the ERE-LuC plasmid.

\section{References}

BALAGUER P, BOUSSIOUX AM, DEMIRPENCE E, NICOLAS JC (2001). Reporter cell lines are useful tools for monitoring biological activity of nuclear receptor ligands. Luminescence 16: 153-158.
CEDERROTH CR, SCHAAD O, DESCOMBES P, CHAMBON P, VASSALLI JD, NEF S (2007). Estrogen receptor alpha is a major contributor to estrogenmediated fetal testis dysgenesis and cryptorchidism. Endocrinology 148: 55075519.

DELBÈS G, DUQUENNE C, SZENKER J, TACCOEN J, HABERT R, LEVACHER $C$ (2007). Developmental changes in testicular sensitivity to estrogens throughout fetal and neonatal life. Toxicol Sci99: 234-243.

DELBÈS G, LEVACHER C, HABERT R (2006) Estrogen effects on fetal and neonatal testicular development. Reproduction 132: 527-538.

DELBÈS G, LEVACHER C, DUQUENNE C, RACINE C, PAKARINEN P, HABERT $R$ (2005). Endogenous estrogens inhibit mouse fetal Leydig cell development via estrogen receptor alpha. Endocrinology 146: 2454-2461.

DETRE S, SALTER J, BARNES DM, RIDDLER S, HILLS M, JOHNSTON SR, GILLETT C, A'HERN R, DOWSETT M (1999).Time-related effects of estrogen withdrawal on proliferation- and cell death-related events in MCF-7 xenografts. Int J Cancer 81: 309-313.

GAIDO KW, HENSELY JB, LIU L, WALLOCE DG, BORGOFF S, JOHNSON KJ, HALL SJ, BOEKELEIDE E. (2007). Fetal mouse phthalate exposure shows that gonocyte multinucleation is not associated with decreased testicular testosterone. Toxicol Sci97: 491- 503

GRECO TL, FURLOW JD, DUELLO TM, GORSKI J (1992). Immunodetection of estrogen receptors in fetal and neonatal male mouse reproductive tracts. Endocrinology 130: 421-429.

GUYOT R, ODET F, LEDUQUE P, FOREST MG, LE MAGUERESSE-BATTISTONI $B$ (2004). Diethylstilbestrol inhibits the expression of the steroidogenic acute regulatory protein in mouse fetal testis. Mol Cell Endocrino/220: 67-75.

INOUE A, YOSHIDA N, OMOTO Y, OGUCHI S, YAMORI T, KIYAMA R, HAYASHI $S$ (2002). Development of cDNA microarray for expression profiling of estrogenresponsive genes. J Mol Endocrino/29: 175-192.

JEFFERSON WN, COUSE JF, BANKS EP, KORACH KS, NEWBOLD RR (2000) Expression of estrogen receptor beta is developmentally regulated in reproductive tissues of male and female mice. Biol Reprod 62: 310-317.

KLEIN-HITPASS L, TSAI SY, GREENE GL, CLARK JH, TSAI MJ, O'MALLEY BW (1989). Specific binding of estrogen receptor to the estrogen response element. $\mathrm{Mol}$ Cell Bio/9: 43-49.

KUSHNER PJ, AGARD DA, GREENE GL, SCANLAN TS, SHIAU AK, UHT RM, WEBB P (2000). Estrogen receptor pathways to AP-1. J Steroid Biochem Mol Bio/74: 311-317.

LASSURGUĖRE J, LIVERA G, HABERT R, JÉGOU B (2003). Time- and doserelated effects of estradiol and diethylstilbestrol on the morphology and function of the fetal rat testis in culture. Toxico/ Sci73: 160-169.

MAJDIC G, SHARPE RM, SAUNDERS PT (1997). Maternal oestrogen/xenoestrogen exposure alters expression of steroidogenic factor-1 (SF-1/Ad4BP) in the fetal rat testis. Mol Cel/ Endocrino/127: 91-98

MANGELSDORF DJ, THUMMEL C, BEATO M, HERRLICH P, SCHÜTZ G UMESONO K, BLUMBERG B, KASTNER P, MARK M, CHAMBON P, EVANS RM (1995). The nuclear receptor superfamily: the second decade. Cel/83: 835839.

MARTIN PM, HORWITZ KB, MCGUIRE WL (1978). Phytoestrogen interaction with estrogen in human breast cancer cells. Endocrinology 103: 1860-1867.

MCKENNA NJ, LANZ RB, O'MALLEY BW. (1999). Nuclear receptor coregulators: cellular and molecular biology. Endocr Rev20: 321-344.

MOE-BEHRENS GH, KLINGER FG, ESKILD W, GROTMOL T, HAUGEN TB, DE FELICI M (2003). Akt/PTEN signaling mediates estrogen-dependent proliferation of primordial germ cells in vitro. Mol Endocrino/17: 2630-2638.

NIELSEN M, BJÖRNSDÓTTIR S, HøYER PE, BYSKOV AG (2000). Ontogeny of oestrogen receptor alpha in gonads and sex ducts of fetal and newborn mice. $J$ Reprod Fertil118: 195-204.

NORFLEET AM, THOMAS ML, GAMETCHU B, WATSON CS (1999). Estrogen receptoralpha detected on the plasma membrane of aldehyde-fixed $\mathrm{GH} 3 / \mathrm{B} 6 /$ F10 rat pituitary tumor cells by enzyme-linked immunocytochemistry. Endocrinology 140: 3805-3814

OKUBO T, SUZUKI T, YOKOAMA Y, KANO K, KANO I (2003). Estimation of estrogenic and anti-estrogenic activities of some phtalate diesters and monoesters by MCF-7 cell proliferation assay in vitro. Biol Pharm Bu/26: 1219- 
1224.

PESCE M, DE FELICI M (1995). Purification of mouse primordial germ cells by MiniMACS magnetic separation system. Dev Bio/170: 722-725.

RICUPITO A, DEL POZZO G, DIANO N, GRANO V, PORTACCIO M, MARINO M BOLLI A, GALLUZZO P, BONTEMPO P, MITA L, ALTUCCI L, MITA DG (2009). Effect of bisphenol A with or without enzyme treatment on the proliferation and viability of MCF-7 cells. Environ Int 35: 21-6.

SAUNDERS PT, FISHER JS, SHARPE RM, MILLAR MR (1998) Expression of oestrogen receptor beta (ER beta) occurs in multiple cell types, including some germ cells, in the rat testis. J Endocrino/156: 13-17.

SHARPE RM, SKAKKEBAEK NE (1993). Are oestrogens involved in falling sperm counts and disorders of the male reproductive tract? Lancet 341: 1392-1395.

SHIER WT, SHIER AC, XIE W, MIROCHA CJ (2001) Structure-activity relationships for human estrogenic activity in zeralenone mycotoxins. Toxicology 39: 1435-1438.

SKAKKEBAEK NE, RAJPERT-DE MEYTS E, MAIN KM (2001). Testicular dysgenesis syndrome: an increasingly common developmental disorder with environmental aspects. Hum Reprod 16: 972-978.
STEINMETZ R, YOUNG PC, CAPERELL-GRANT A, GIZE EA, MADHUKAR BV BENJONATHAN N, BIGSBY RM (1996). Novel estrogenic action of the pesticide residue betahexachlorocyclohexane in human breast cancer cells. Cancer Res 56: 5403-5409.

TRAINA ME, RESCIA M, URBANI E, MANTOVANI A, MACRÌ C, RICCIARDI C STAZI AV, FAZZI P, CORDELLI E, ELEUTERI P, LETER G, SPANÒ ML (2003). Long lasting effect of lindane on mouse spermatogenesis induced by in utero exposure. Repr Bio/17: 25-35.

TRUCHET I, JOZAN S, GUERRIN M, MAZZOLINI L, VIDAL S, VALETTE A (2000) Interconnections between E2-dependent regulation of cell cycle progression and apoptosis in MCF-7 tumors growing on nude mice. Exp Cel/ Res 254: 241 248.

VICINI E, LOIARRO M, DI AGOSTINO S, CORALLINI S, CAPOLUNGHI F CARSETTI R, CHIEFFI P, GEREMIA R, STEFANINI M, SETTE C (2006). 17 beta-estradiol elicits genomic and non-genomic responses in mouse male germ cells. J Cell Physio/206: 238-245.

WASHINGTON W, HUBERT L, JONES D, GRAY WG (2001). Bisphenol A binds to the low-affinity estrogen binding site. In Vitr Mol Toxicol14: 43-50.

\section{Further Related Reading, published previously in the Int. J. Dev. Biol.}

See Special Issue Pattern Formation edited by Michael K. Richardson and Cheng-Ming Chuong at:

http://www.ijdb.ehu.es/web/contents.php?vol=53\&issue=5-6

The spatio-temporal pattern of testis organogenesis in mammals - insights from the mole Francisco D. Carmona, Darío G. Lupiáñez, José-Ezequiel Martín, Miguel Burgos, Rafael Jiménez and Federico Zurita

Int. J. Dev. Biol. (2009) 53: 1035-1044

Abnormal sex-duct development in female moles: the role of anti-Müllerian hormone and testosterone.

Federico Zurita, Francisco J Barrionuevo, Philippe Berta, Esperanza Ortega, Miguel Burgos and Rafael Jiménez

Int. J. Dev. Biol. (2003) 47: 451-458

Germ cells, gonads and sex reversal in marsupials.

M B Renfree and G Shaw

Int. J. Dev. Biol. (2001) 45: 557-567

An mRNA differential display strategy for cloning genes expressed during mouse gonad development.

K Nordqvist and V Töhönen

Int. J. Dev. Biol. (1997) 41: 627-638

The role of the mesonephros in cell differentiation and morphogenesis of the mouse fetal testis.

$\mathrm{H}$ Merchant-Larios, N Moreno-Mendoza and M Buehr

Int. J. Dev. Biol. (1993) 37: 407-415

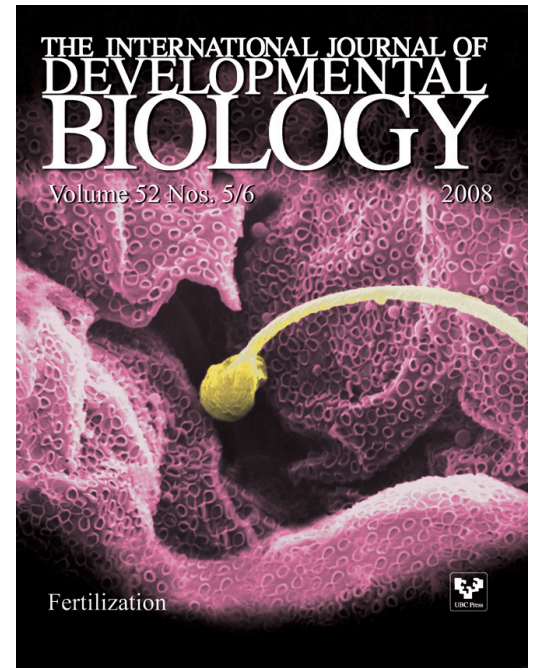

5 yr ISI Impact Factor $(2008)=3.271$

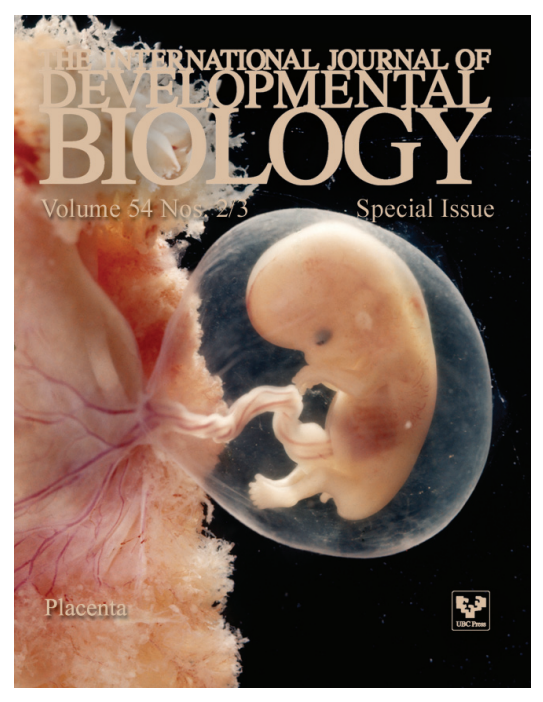

